\section{Phosphorus Sources and Management in Organic Production Systems}

\author{
Nathan O. Nelson ${ }^{1,3}$ and Rhonda R. Janke ${ }^{2}$
}

ADDITIONAL INDEX WORDs. rock phosphate, bone meal, manure, compost, mycorrhiza, organic agriculture, environmental protection, eutrophication, cover crops, green manure

SUMMARY. Organically produced fruit and vegetables are among the fastest growing agricultural markets. With greater demand for organically grown produce, more farmers are considering organic production options. Furthermore, there is an increasing interest in maintaining optimal production in an organic system, which involves appropriate nutrient management. The objectives of this review were to summarize the current state of our knowledge concerning effects of organic production systems on phosphorus $(P)$ availability, describe $P$ availability in common organically accepted $P$ sources, and review best management practices that can reduce environmental risks associated with $\mathbf{P}$ management in organic systems. Organic production systems seek to improve soil organic matter and biological diversity, which may impact $P$ cycling and $P$ uptake by crops. Increases in organic matter will be accompanied by an increase in the organic $P$ pool. Furthermore, management of cover crops and potentially enhanced arbuscular mycorrhizal fungi colonization from organic production practices can increase the availability of soil $P$ pool (both organic and inorganic) by stimulating microbial activity and release of root exudates. This can help compensate for low soil $\mathrm{P}$, but will not supersede the need to replace $P$ removed by the harvested crop. Phosphorus fertilization in organic production systems entails balancing the $P$ inputs with crop removal through selection and management of both nitrogen $(N)$ and $P$ inputs. Organic production systems that rely on manure or composts for meeting crop $\mathrm{N}$ demand will likely have a $P$ surplus; therefore, $P$ deficiencies will not be an issue. Systems using other $\mathbf{N}$ sources may have a $\mathbf{P}$ deficit, therefore requiring $\mathbf{P}$ supplementation for optimal plant growth. In such situations, maintenance $P$ applications equal to crop removal should be made based on soil test recommendations. Primary organically approved $P$ sources are phosphate rock (PR), manure, and compost. Phosphate rock is most effective at supplying $P$ in soils with low $\mathrm{pH}$ (less than 5.5) and low calcium concentrations. Phosphate rock applications made to soils with $\mathrm{pH}$ greater than 5.5 may not be effective because of reduced PR solubility. Manure- and compost-based $\mathrm{P}$ has high plant availability, ranging from $70 \%$ to $100 \%$ available. Use of manures and composts requires extra considerations to reduce the risk of $P$ loss from $P$ sources to surface waters. Best management practices (BMPs) for reducing source $P$ losses are incorporation of the manures or composts and timing applications to correspond to periods of low runoff risk based on climatic conditions. Organic production systems that use manures and composts as their primary $\mathbf{N}$ source should focus on minimizing $\mathbf{P}$ buildup in the soils and use of management practices that reduce the risks of $\mathbf{P}$ loss to surface waters. Evaluation of $P$ loss risk with a $P$ index will assist in identification of soil and management factors likely to contribute to high P loss as well as BMPs that can decrease P loss risks. BMPs should focus on controlling both particulate and dissolved $\mathrm{P}$ losses.

$\mathrm{P}$ hilosophies of nutrient management in organic production systems focus on maintaining agricultural productivity with minimal inputs (Elmaz et al., 2004;

Contribution No. 07-197-J from the Kansas Agricultural Experiment Station, Manhattan, KS

${ }^{1}$ Kansas State University, Department of Agronomy, 2708 Throckmorton Plant Sciences Center, Manhattan, KS 66506

${ }^{2}$ Kansas State University, Department of Horticulture, Forestry, and Recreation Resources, 2021 Throckmorton Plant Sciences Center, Manhattan, KS 66506

${ }^{3}$ Corresponding author. E-mail: nonelson@ksu.edu.
Stockdale et al., 2001). The end goal of nutrient management in organic agriculture is to produce food in a more environmentally sustainable system that takes advantage of internal nutrient cycling and reduces losses (Stockdale et al., 2002; Watson et al., 2002a). Nutrient inputs to organic production systems are focused on carbon-based nutrient sources (e.g., crop residue, compost, manure) and nonprocessed mineral sources (e.g., rock phosphate, lime, gypsum). As such, nutrient management in organic production systems is fundamentally different from that in conventional systems. Phosphorus (P) management is of particular interest because the $P$ sources approved for use in organic agriculture have diverse characteristics. Phosphorus management can also have a strong influence on the environmental impact of crop production because $\mathrm{P}$ is a leading contributor to water quality degradation (Correll, 1998). Furthermore, nitrogen $(\mathrm{N})$ management decisions in organic production often influence $\mathrm{P}$ availability for crop use and potential risks of $\mathrm{P}$ loss to the environment.

Phosphorus is an essential element for plant growth and is involved in many plant metabolic functions. Most notably, $\mathrm{P}$ is an essential component of adenosine diphosphate and adenosine triphosphate-organic molecules that are used for energy storage and transfer. Phosphorus is also a structural component of nucleotides, phospholipids, phosphoproteins, and coenzymes (Havlin et al., 2004). Therefore, sustainable agricultural production is dependent on the maintenance of adequate $\mathrm{P}$ availability by the soil or other P inputs to the system.

Compared with undisturbed ecosystems, agricultural systems shortcircuit complete $\mathrm{P}$ cycling because $\mathrm{P}$ in harvested crops is removed from fields, introduced into the human food chain, and processed through the waste stream (Fig. 1). This open cycle creates a $\mathrm{P}$ deficit in soils without P additions (Newman, 1997). Several studies investigating wholefarm P budgets have found annual P deficits in organic production systems and conclude that these systems are

\begin{tabular}{llll}
\hline $\begin{array}{l}\text { Units } \\
\begin{array}{l}\text { To convert U.S. to SI, } \\
\text { multiply by }\end{array}\end{array}$ & U.S. unit & SI unit & $\begin{array}{l}\text { To convert SI to U.S., } \\
\text { multiply by }\end{array}$ \\
\hline 1.1209 & $\mathrm{lb} / \mathrm{acre}$ & $\mathrm{kg} \cdot \mathrm{ha}^{-1}$ & 0.8922 \\
1 & micron & $\mu \mathrm{m}$ & 1 \\
1 & $\mathrm{ppm}$ & $\mathrm{mg} \cdot \mathrm{kg}^{-1}$ & 1 \\
1 & $\mathrm{ppm}$ & $\mathrm{mg} \cdot \mathrm{L}^{-1}$ & 1 \\
2.2417 & ton/acre & $\mathrm{Mg} \cdot \mathrm{ha}^{-1}$ & 0.4461
\end{tabular}


mining P reserves built up from previous $P$ inputs when soils were under conventional management (Berry et al., 2003; Gosling and Shepherd, 2005; Watson et al., 2002b). As illustrated in Figure 2, long-term research studies have found drastic declines in production capacity for systems lacking $\mathrm{P}$ inputs (Dodd and Mallarino, 2005). Because $P$ is an essential nutrient for plant growth, sustainable systems should at a minimum replace the $\mathrm{P}$ removed in harvested crops to avoid such yield declines. Although organic agriculture seeks to maintain minimal inputs, it is advised that producers replace $P$ removed in harvested crops (Gosling and Shepherd, 2005; Horst et al., 2001).

Although some organic farms may run a $P$ deficit, others are likely to have a P surplus because many organic production systems rely on manures or composts as $\mathrm{N}$ sources. According to a poll conducted by the Organic Farming Research Foundation, compost and manure applications are regularly made by $57 \%$ and $22 \%$ of U.S. organic producers, respectively (Walz, 1999). Farms that use compost or manure to meet crop $\mathrm{N}$ requirements will generally have a P surplus (Mikkelsen, 2000). Although P requirements for crop growth are not a concern in these management systems, sustainable $\mathrm{P}$ management must include measures to minimize P losses to surface waters.

Phosphorus management in organic production systems should therefore consider cropping system effects on $\mathrm{P}$ availability, $\mathrm{N}$ amendments and concomitant $\mathrm{P}$ applications, $P$ sources and availability, and best management practices to reduce $\mathrm{P}$ losses. The objectives of this review are to present the current state of knowledge concerning $\mathrm{P}$ management with respect to organic production systems, including: 1) changes in soil properties that would affect $\mathrm{P}$ availability, 2) nitrogen source effects on $\mathrm{P}$ management, 3) $\mathrm{P}$ availability from $\mathrm{P}$ sources approved for use in organic agriculture, and 4) management methods useful to reducing $\mathrm{P}$ losses and for environmental protection.

\section{Organic agriculture effects on soil properties and phosphorus availability}

Soil processes that affect $P$ cycling and availability in organically

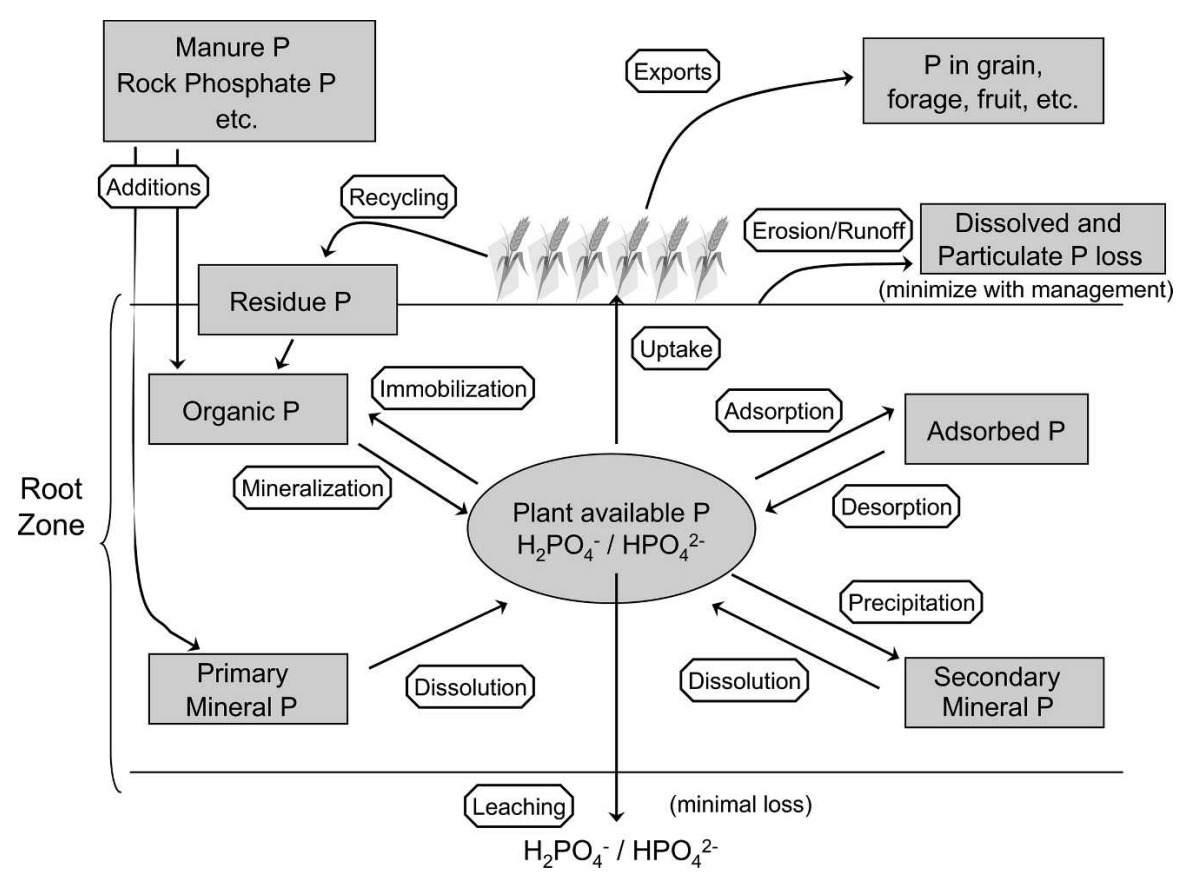

Fig. 1. The phosphorus $(P)$ cycle in organic production systems, including $P$ additions, exports, cycling, and transformations within the soil. Plant-available $\mathbf{P}$ is present as inorganic orthophosphate species $\mathrm{HPO}_{4}{ }^{2-}$ and $\mathrm{H}_{2} \mathrm{PO}_{4}{ }^{-}$. Phosphorus cycles in conventional systems would have different additions (chemical fertilizers) that would directly supply plant-available P. Phosphorus cycling in unmanaged ecosystems would have no harvest removal and no $P$ additions.

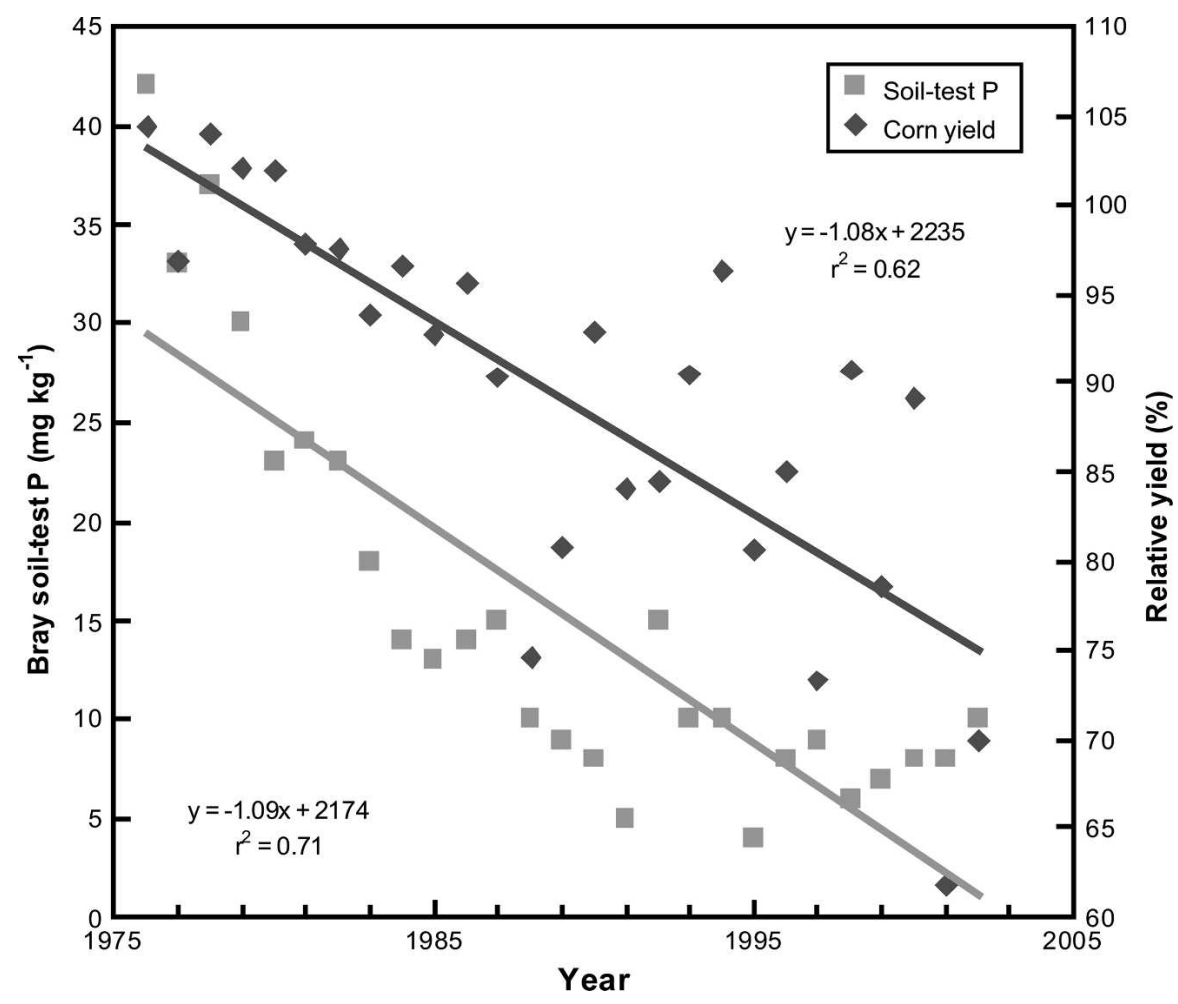

Fig. 2. Decline in soil test phosphorus $(P)$ and relative corn yield after 27 years of continuous cropping without addition of $P$ fertilizer. Yield is relative to corn plots receiving $33 \mathrm{~kg} \cdot \mathrm{ha}^{-1}(29.4 \mathrm{lb} / \mathrm{acre}) \mathrm{P}$ per year. Data from Dodd and Mallarino, $2005 ; 1 \mathrm{mg} \cdot \mathrm{kg}^{-1}=1 \mathrm{ppm}$. 
managed soils are not different from those in conventionally managed soils, but the relative importance of $\mathrm{P}$ cycling may differ between the two systems (Stockdale et al., 2002). Organic production potentially affects a number of soil properties, including soil organic matter content, microbial activity, microbial community structure, soil aggregation, water-holding content, and soil chemistry, which could potentially affect P availability (Stockdale et al., 2001). Organic production systems often contain more diverse crop rotations, including cover crops, which may also alter nutrient cycling. The primary means by which organic production practices would influence $P$ availability would be through alteration of soil organic matter content, increased $P$ availability from degradation of cover crop residues, and increased arbuscular mycorrhizal fungi (AMF) colonization resulting from lack of soluble $\mathrm{P}$ fertilizer applications. Management practices common to organic systems that influence $P$ availability are reviewed briefly to place them in perspective relative to the management of applied $\mathrm{P}$ sources.

SoIL ORganic MatTer. Many long-term experiments comparing conventional and organic practices have documented increased organic matter/carbon accumulation in organically managed soils (Clark et al., 1998; Drinkwater et al., 1998; Liebig and Doran, 1999; Lotter, 2003; Reganold et al., 1993). However, some long-term research experiments (Mader et al., 2002) and on-farm comparisons (Gosling and Shepherd, 2005 ) did not find increases in soil organic matter resulting from organic production practices. Whether there is in fact any increase at all depends on the specific practices used in the organic and conventional systems (crop residue return, manure and compost application, tillage, and so on). Several studies have shown an increase in the concentration of total $\mathrm{P}$ in organic production systems (Lotter, 2003); however, other studies have shown a decrease in the mineral or available $\mathrm{P}$ pools (Gosling and Shepherd, 2005; Mader et al., 2002).

Increased soil organic matter content could increase plant $\mathrm{P}$ uptake by decreasing bulk density and increasing porosity, thereby improving root exploration and effectiveness. In addition, the organic $\mathrm{P}$ pool increases with increasing organic matter. Organic P compounds such as inositol phosphates, nucleic acids, and phospholipids present in organic matter can be mineralized during organic matter decomposition, thereby increasing $\mathrm{P}$ availability and acting as a $P$ source for future crops. Increasing the availability of the organic matter $P$ pool has been the subject of considerable research on both cover crops and AMF.

Cover Crops. Cover crops grown before cash crops take up soil $\mathrm{P}$ and then release it as the cover crop decomposes. In an incubation study, a legume amended soil released 0.27 $\mathrm{mg} \cdot \mathrm{kg}^{-1} \mathrm{P}$ per day over $21 \mathrm{~d}$ versus $0.06 \mathrm{mg} \cdot \mathrm{kg}^{-1} \mathrm{P}$ per day for an unamended soil (Randhawa et al., 2005). In addition, some cover crops release root exudates such as carboxylates, enabling uptake of soil $\mathrm{P}$ that is not available to other plants (Nuruzzaman et al., 2005). However, when various legume cover crops have been compared for their effectiveness in making $\mathrm{P}$ available to subsequent crops, the results have not always been predictable.

In a pot experiment using soils from Western Australia, fava bean (Vicia faba) promoted more growth and $\mathrm{P}$ uptake in subsequent wheat (Triticum aestivum) than the other legumes in the experiment, including white lupin (Lupinus albus) and field pea (Pisum sativum), which both had larger amounts of rhizosphere carboxylates than the fava bean (Nuruzzaman et al., 2005). The P content of the fava bean was significantly higher than the other legumes at all soil $\mathrm{P}$ levels, or almost double, on a per-pot basis despite the lack of rhizosphere carboxylates. The authors suggest that the $\mathrm{P}$ benefits to the wheat in their experiment were the result of the mineralization of the organic $\mathrm{P}$ from the fava bean rather than carboxylateinduced changes in soil chemistry.

Cavigelli and Thien (2003) found in a greenhouse pot study that sorghum (Sorghum bicolor) P uptake was positively correlated with $\mathrm{P}$ uptake of the preceding perennial forage cover crops [alfalfa (Medicago sativa), red clover (Trifolium pratense), and sweet clover (Melilotus officinalis)] but not correlated with $P$ uptake of winter annual cover crops.
For example, white lupin biomass and $\mathrm{P}$ uptake were two to three times greater than the other winter cover crops [austrian winter pea (Pisum sativum ssp. sativum var. arvense), vetch (Vicia villosa), and wheat], and yet sorghum P uptake after lupin was lower than all other treatments, including the control. In this case, cover crop species rather than $P$ uptake seemed to influence subsequent sorghum P uptake. Furthermore, they found that cover crops that resulted in greater $\mathrm{P}$ uptake by the subsequent sorghum crop also caused greater declines in soil test $\mathrm{P}$, thus illustrating that although cover crops may increase P uptake, it may be at the expense of other $\mathrm{P}$ pools that will need to be replenished to maintain production. They also suggest that a soil test measuring microbial activity and other changes in soil characteristics may be more useful for measuring $\mathrm{P}$ availability after incorporation of legumes than traditional soil testing (e.g., the Bray Pl test).

In a West African sorghum cropping system, crotalaria (Crotalaria retusa) used as a green manure was superior to cowpea (Vigna unguiculata), and both resulted in more yield from a subsequent corn (Zea mays) crop than sorghum in rotation. However, all treatments responded to additional single superphosphate $\left[\mathrm{Ca}\left(\mathrm{H}_{2} \mathrm{PO}_{4}\right)_{2} \cdot \mathrm{H}_{2} \mathrm{O} \quad(0 \mathrm{~N}-7.9 \mathrm{P}-0 \mathrm{~K})\right]$ applications, demonstrating that the green manure cover crops did not supply enough $\mathrm{P}$ to overcome $\mathrm{P}$ limitation (Muleba, 1999). Similar results were obtained by Horst et al. (2001) in testing 16 legume cover crops in a corn-based cropping system in Nigeria. On one of the two soils tested, corn P uptake was correlated with phosphate application in the preceding cover crops. The covercropped soils also had higher rates of AMF infection.

These results indicate that total uptake of $\mathrm{P}$ by a prior cover crop is important, but at the same time, some responses, both positive and negative, seem to be species-specific and may be microbially mediated. A closer look at the relationship among green manures, $\mathrm{P}$, and root colonizing mycorrhizal fungi may help explain some of these relationships.

Arbuscular mycorrhizal FUNGI COLONIZATION. Enhanced P 
uptake is generally understood to be one of the most important benefits of AMF colonization. In return, the host plant provides carbohydrates usually, but not always, without detrimental effects to the host. Additional benefits of AMF colonization include increased tolerance to water stress and occasional suppression of crop pests and diseases, although this is less consistently observed than effects on nutrient uptake (Gosling et al., 2006; Jeffries et al., 2003). Arbuscular mycorrhiza fungi are also important in helping to form waterstable aggregates, an indicator of soil quality. Over $80 \%$ of plant species can serve as AMF hosts. Notable exceptions sometimes used as crops or rotation crops in organic systems include plants in the Brassiceae and the Chenopodiaceae families.

Many practices used by organic farmers promote AMF, including the use of cover crops (Galvez et al., 1995), and reduced use of biocides and soluble fertilizers (Gosling et al., 2006; Jeffries et al., 2003), although the effect of any particular biocide may be difficult to predict and is not always negative (Gosling et al., 2006). Reduced tillage also leads to higher rates of colonization with AMF, probably as a result of lack of disruption of the common mycorrhizal hyphae network (Galvez et al., 1995; Gosling et al., 2006). Frequent or deep tillage used by many organic farmers for weed control can reduce AMF abundance as can bare or fallow soil. The degree and frequency of tillage will depend on the cropping system. Rotation with perennial legumes could potentially compensate for some of the AMF reduction occurring during parts of the rotation cycle with frequent tillage.

AMF colonization appears to be greater in low $\mathrm{P}$ soils rather than high, although application of $\mathrm{P}$ in the form of manures and composts does not always inhibit colonization (Gosling et al., 2006). An organic system with animal manure additions in a longterm Pennsylvania experiment had higher levels of soil $\mathrm{P}$ and also higher populations of AMF spores and colonized roots as compared with a conventional cropping system (Douds et al., 1993).

In a greenhouse study with leeks (Allium porrum), AMF increased $\mathrm{P}$ uptake from bone meal by $62 \%$ but did not enhance P uptake from Kola apatite, a form of igneous rock phosphate (Kahiluoto and Vestberg, 1998). Inoculation with AMF in a field trial increased growth and $\mathrm{P}$ uptake by leeks on a conventional soil, but had a slight negative effect on leeks on an organically managed soil, which had higher $\mathrm{P}$ and AMF levels compared with the conventional soil at the initiation of the experiment. Their conclusion was that working with indigenous AMF through systems management on organic farms has more potential than inoculation (Kahiluoto and Vestberg, 1998).

In summary, although AMF can help compensate for low $\mathrm{P}$ in some organic systems, even with good colonization, this does not always translate into higher yields (Gosling et al., 2006; Jeffries et al., 2003). However, other benefits can accrue from AMF colonization, even with relatively high soil P levels, and organic farmers will often be using practices that promote higher AMF levels compared with conventional farmers. If soils are low in $\mathrm{P}$, both cover crops and AMF can help increase uptake of $\mathrm{P}$ that is present, but farmers are advised to supplement with forms of $\mathrm{P}$ allowable under organic certification standards to meet overall crop needs and maintain a sufficient $P$ balance in the system (Gosling and Shepherd, 2005).

\section{Nitrogen source effects on phosphorus}

Nitrogen sources used for organic production can have a strong impact on $\mathrm{P}$ availability, field-level $\mathrm{P}$ balance, and $\mathrm{P}$ management strategies. Animal manures and composts contain both $\mathrm{N}$ and $\mathrm{P}$; however, the available $\mathrm{N}: \mathrm{P}$ ratios in most manures and composts are less than that required by plants. For example, the average $N: P$ ratio in the harvested portion of crop biomass is $7: 1$ with a minimum of $4: 1$ (Table 1 ); however, the $\mathrm{N}: \mathrm{P}$ ratio of animal manures is frequently less than 4:1 (Table 2). Because not all $\mathrm{N}$ in manure is available for crop uptake, manure-based $\mathrm{N}$ application rates are calculated with potentially available $\mathrm{N}$ (PAN) concentrations in manure (Gaskell and Smith, 2007). Nitrogen availability of manure can range from $25 \%$ to $70 \%$ of total N (Pierzynski et al., 1994); therefore, PAN:P ratios would be $30 \%$ to $75 \%$ less than the $\mathrm{N}: \mathrm{P}$ ratios presented in Table 2 depending on manure characteristics and methods of application. This illustrates that the use of manure to meet crop $\mathrm{N}$ requirement will generally oversupply $\mathrm{P}$, exceeding crop removal by as much as four times. Overapplication of $\mathrm{P}$ is not detrimental to crop growth or yields, but excess P applications will increase soil test $P$ levels far beyond crop requirements (Daniel et al., 1994). Both high $\mathrm{P}$ application rates and high soil test $\mathrm{P}$ can increase the risk of environmental damage resulting from $\mathrm{P}$ losses to surface waters, as discussed in a later section.

Phosphorus and $\mathrm{N}$ concentrations of manures and composts vary dramatically based on the animal species, feeding regime, processing, and composting substrates (Table 2 ). In general, poultry litters have higher $\mathrm{P}$ concentrations and lower $\mathrm{N}: \mathrm{P}$ ratios than other manures. Manure from organically raised livestock may have lower P concentrations (Haas et al., 2002), but PAN:P ratios would still be less than what would be required by crops. Compost is more frequently applied in organic production than is manure because nutrients in compost are more stable and believed to be more environmentally benign (Seiter and Horwath, 2004; Walz, 1999). It is important to note that composting manures further decreases $\mathrm{N}: \mathrm{P}$ ratios because $\mathrm{P}$ is conserved during the composting process, whereas some of the $\mathrm{N}$ is lost (Table 2). Furthermore, composts have lower $\mathrm{N}$ availability than manures (Hadas et al., 1996), exacerbating the disparity between the PAN:P ratio of compost versus $\mathrm{N}: \mathrm{P}$ ratio in harvested crop biomass. However, yard waste compost (without added manure) has the highest $\mathrm{N}: \mathrm{P}$ ratio of the organically based $\mathrm{N}$ sources listed in Table 2 . Although use of yard waste compost as a primary $\mathrm{N}$ source could help balance $\mathrm{P}$ inputs with $\mathrm{P}$ removal, its availability and relatively low $\mathrm{N}$ concentration would limit its widespread use.

Organic producers using manures and composts as a major $\mathrm{N}$ source will likely have high soil test $\mathrm{P}$ and their $\mathrm{P}$ management strategies should focus on reducing $\mathrm{P}$ losses 
Table 1. Average yields, nitrogen $(\mathrm{N})$ removal, phosphorus $(\mathrm{P})$ removal, and N:P ratios for harvested portions of common grain, forage, fruit, and vegetable crops. ${ }^{\mathrm{z}}$

\begin{tabular}{|c|c|c|c|c|c|}
\hline Crop (common name) & Genus and species & Yield $\left(\mathrm{Mg} \cdot \mathrm{ha}^{-1}\right)^{\mathrm{y}}$ & $\mathrm{N}$ removal $\left(\mathrm{kg} \cdot \mathrm{ha}^{-1}\right)^{\mathrm{y}}$ & P removal $\left(\mathrm{kg} \cdot \mathrm{ha}^{-1}\right)$ & $\mathrm{N}: \mathrm{P}$ ratio \\
\hline \multicolumn{6}{|l|}{ Grain crops } \\
\hline Barley & Hordeum vulgare & 2.2 & 39.2 & 7.3 & 5.3 \\
\hline Corn & Zea mays & 9.4 & 151.3 & 25.9 & 5.8 \\
\hline Rice & Oryza sativa & 4.0 & 56.0 & 9.8 & 5.7 \\
\hline Rye & Secale cereale & 1.9 & 39.2 & 4.9 & 8.0 \\
\hline Bean, dry & Phaseolus vulgaris & 2.0 & 84.0 & 12.2 & 6.9 \\
\hline Soybean & Glycine max & 2.7 & 168.1 & 17.1 & 9.8 \\
\hline \multicolumn{6}{|l|}{ Forage crops } \\
\hline Alfalfa & Medicago sativa & 9.0 & 201.7 & 19.6 & 10.3 \\
\hline Bluegrass & Poa annua & 4.5 & 67.2 & 9.8 & 6.9 \\
\hline Coastal bermuda & Cynodon dactylon & 17.9 & 336.2 & 34.3 & 9.8 \\
\hline Soybean & Glycine max & 4.5 & 100.9 & 9.8 & 10.3 \\
\hline Timothy & Phleum pretense & 5.6 & 67.2 & 12.2 & 5.5 \\
\hline \multicolumn{6}{|c|}{ Fruit and vegetable crops } \\
\hline Apple & Malus pumila & 26.9 & 33.6 & 4.9 & 6.9 \\
\hline Orange & Citrus sinensis & 62.8 & 95.3 & 14.7 & 6.5 \\
\hline Peach & Prunus persica & 33.6 & 39.2 & 9.8 & 4.0 \\
\hline Cabbage & Brassica oleracea var. capitata & 44.8 & 145.7 & 17.1 & 8.5 \\
\hline Onion & Allium сера & 16.8 & 50.4 & 9.8 & 5.2 \\
\hline Potato & Solanum tuberosum & 26.9 & 89.7 & 14.7 & 6.1 \\
\hline Spinach & Spinacia oleracea & 11.2 & 56.0 & 7.3 & 7.6 \\
\hline Sweet potato & Ipomoea batatas & 18.5 & 50.4 & 7.3 & 6.9 \\
\hline Tomato & Lycopersicon esculentum & 44.8 & 134.5 & 19.6 & 6.9 \\
\hline
\end{tabular}

${ }^{\mathrm{z}}$ Eakin, 1976.

${ }^{\mathrm{y}} \mathrm{l} \mathrm{Mg} \cdot \mathrm{ha}^{-1}=0.4461 \mathrm{ton} / \mathrm{acre}, \mathrm{l} \mathrm{kg} \cdot \mathrm{ha}^{-1}=0.8922 \mathrm{lb} /$ acre.

Table 2. Average nitrogen $(\mathrm{N})$ and phosphorus $(\mathrm{P})$ concentrations reported for various manures and composts.

\begin{tabular}{|c|c|c|c|c|c|c|c|}
\hline \multirow[b]{2}{*}{ Nutrient source } & \multirow[b]{2}{*}{$\mathbf{n}$} & \multirow{2}{*}{$\mathbf{N}$} & \multirow{2}{*}{$\frac{\mathbf{P}}{\mathbf{z}}$} & \multicolumn{3}{|c|}{$\mathrm{N}: \mathrm{P}$ ratio } & \multirow[b]{2}{*}{ References $^{\mathrm{y}}$} \\
\hline & & & & Maximum & Avg & Minimum & \\
\hline \multicolumn{8}{|l|}{ Manures } \\
\hline Dairy & 16 & 34.4 & 8.4 & 6.6 & 4.2 & 1.7 & $5,6,7,8$ \\
\hline Poultry & 14 & 38.2 & 21.0 & 2.9 & 1.9 & 1.3 & $6,7,9,10,11,12$ \\
\hline Swine & 7 & 39.7 & 14.0 & 4.3 & 2.7 & 2.0 & $2,6,7,13$ \\
\hline Dairy & 8 & 25.5 & 13.5 & 3.2 & 2.0 & 0.7 & 14 \\
\hline Poultry & 6 & 23.8 & 20.3 & 1.8 & 1.1 & 0.6 & $9,10,14,15$ \\
\hline Swine & 7 & 14.0 & 7.6 & 2.4 & 1.9 & 1.4 & 13,16 \\
\hline Yard waste & 25 & 14.6 & 2.5 & 12.9 & 6.7 & 1.1 & $10,14,17,18,19,20$ \\
\hline Yard waste $+^{\mathrm{x}}$ & 5 & 15.4 & 7.9 & 2.4 & 1.6 & 0.4 & 21,22 \\
\hline
\end{tabular}

${ }^{\mathrm{z}} \mathrm{lg} \cdot \mathrm{kg}^{-1}=1000 \mathrm{ppm}$

y(1) Eghball and Power, 1999; (2) Eghball et al., 2005; (3) Larney et al., 2006; (4) Zvomuya et al., 2006; (5) He et al., 2004; (6) Kleinman et al., 2002; (7) Montgomery et al., 2005; (8) Toth et al., 2006; (9) DeLaune et al., 2006; (10) Faucette et al., 2004; (11) Read et al., 2006; (12) Sleugh et al., 2006; (13) McAndrews et al., 2006; (14) Gagnon, 2004; (15) Sikora and Enkiri, 2005; (16) Singer et al., 2004; (17) Jaber et al., 2006; (18) Lisk et al., 1992a; (19) Lisk et al., 1992b; (20) Michel and Reddy, 1998; (21) Felton et al., 2004; (22) Klock-Moore, 2000.

'Yard waste cocomposted with other nutrient sources.

to surface waters. On the other hand, organic producers who use manures and composts sparingly or not at all will likely have greater crop $\mathrm{P}$ removal than $P$ inputs and may need supplemental $\mathrm{P}$ sources to sustain adequate crop production. Soil testing and knowledge of management history will be the best tools for indicating if $\mathrm{P}$ is a limiting nutrient in the production system. 


\section{Phosphorus sources in organic agriculture}

Phosphorus sources approved for use in organic agriculture have diverse properties that affect $\mathrm{P}$ availability and management. Common $\mathrm{P}$ sources include rock phosphate, manure, and compost, all of which are frequently used in research studies. Bone meal and guano are among the less commonly cited $\mathrm{P}$ sources but can have high $\mathrm{P}$ contents (ranging from $7 \%$ to $12 \%$ and $1 \%$ to $9 \%$, respectively).

Phosphate rock. Direct application of phosphate rock (PR) to soils as a $\mathrm{P}$ fertilizer has been practiced for over 100 years. Because direct application of PR continues to be an important $\mathrm{P}$ source in developing nations, there is a wealth of research addressing soil, crop, and PR effects on $\mathrm{P}$ availability, including three extensive reviews compiled during the last 30 years (Kasawneh and Doll, 1978; Rajan et al., 1996; Zapata and Roy, 2004). Phosphate rock is a slowly soluble P source. Although the total $\mathrm{P}$ concentration can be relatively high (greater than $15 \%$ ), the soluble $\mathrm{P}$ concentration can be very low (less than $1 \%$ ). Therefore, a few basic issues must be considered when evaluating the use of $P R$ as a direct $P$ source in agriculture, including PR properties, soil properties, climate, crop species, and soil management practices.

Although the phosphate compound found in PR is always some form of the mineral apatite $\left[\mathrm{Ca}_{5}\left(\mathrm{PO}_{4}\right)_{3} \mathrm{X}\right.$, where $\mathrm{X}$ is an anion], the chemical and mineralogical properties, and therefore solubility, vary greatly between PR sources. Soluble $\mathrm{P}$ concentration of $\mathrm{PR}$ is determined and expressed as water- and citratesoluble $\mathrm{P}$, similar to the methods used for conventional P fertilizers. Phosphate rocks with greater soluble $\mathrm{P}$ concentrations will generally have greater agronomic effectiveness (Zaharah and Bah, 1997). However, both the total $\mathrm{P}$ concentration and the soluble $\mathrm{P}$ concentration should be considered when deciding on PR sources (Van Kauwenbergh and McClellan, 2004). Particle size also affects PR reactivity, in which decreasing particle size down to $\approx 150 \mu \mathrm{m}$ increases PR effectiveness (Kasawneh and Doll, 1978). Decreasing PR particle size to less than $150 \mu \mathrm{m}$ can be cost-prohibitive and does not result in additional agronomic benefit.

Phosphate rock sources can be generally classified as either sedimentary or igneous. Sedimentary PR has higher carbonate substitution and up to 20 times greater specific surface area than igneous rocks (Van Kauwenbergh and McClellan, 2004). Increases in carbonate substitution and specific surface area increase P solubility and make sedimentary PR sources better suited to direct application to soils. Phosphate rock sources known to have consistently high $\mathrm{P}$ availability are located in North Carolina and Gafsa, Tunisia (Table 3); however, North Carolina PR is only used for production of processed phosphate concentrates and cannot be obtained as a raw phosphate ore now. Phosphate rock from the western United States has among the lowest solubility of PR worldwide (Van Kauwenbergh and McClellan, 2004). Although the PR source mine and mineralogy have a strong influence on PR solubility and $\mathrm{P}$ availability, this information can be difficult to obtain for PR sold on the retail market.

Soil $\mathrm{pH}$ is one of the primary soil factors affecting PR efficacy. When $\mathrm{PR}$ is applied to soils, the apatite dissolves according to the reaction shown in Eq. 1 (Lindsay, 1979):

$$
\begin{aligned}
& \mathrm{Ca}_{5}\left(\mathrm{PO}_{4}\right)_{3} \mathrm{~F}+6 \mathrm{H}^{+} \rightleftharpoons 5 \mathrm{Ca}^{2+}+3 \mathrm{H}_{2} \mathrm{PO}_{4}^{-} \\
& +\mathrm{F}^{-} \quad \log \mathrm{K}=-0.21 .
\end{aligned}
$$

Although Eq. 1 equation is for fluorapatite, the general expression applies equally to other apatite minerals. As can be seen in Eq. 1, an increase in the $\mathrm{H}^{+}$concentration (decrease in $\mathrm{pH}$ ) shifts the reaction toward the reactants and increases phosphate concentration. By fixing the $\mathrm{Ca}^{2+}$ and $\mathrm{F}^{-}$activities at $10^{-2.5}$ and $10^{-4} \mathrm{~mol} \cdot \mathrm{L}^{-1}$, respectively, the phosphate concentration can be determined as a function of $\mathrm{pH}$ as follows:

$$
\log \left(\mathrm{H}_{2} \mathrm{PO}_{4}^{-}\right)=5.43-2 \mathrm{pH} \text {. }
$$

Equation 2 illustrates that when other variables are constant, each unit increase in $\mathrm{pH}$ decreases phosphate concentration by two orders of magnitude. For example, phosphate concentration from fluorapatite dissolution would decrease from 0.8 $\mathrm{mg} \cdot \mathrm{L}^{-1}$ at $\mathrm{pH} 5$ to $0.008 \mathrm{mg} \cdot \mathrm{L}^{-1}$ at pH 6.

Because $\mathrm{Ca}^{2+}$ is a reaction product in apatite dissolution, high soil $\mathrm{Ca}^{2+}$ concentrations reduce apatite efficacy as a $\mathrm{P}$ source and soil properties that remove $\mathrm{Ca}^{2+}$ from soil solution will increase dissolution. Soils with high cation exchange capacity and low $\mathrm{Ca}^{2+}$ saturation tend to maintain low $\mathrm{Ca}^{2+}$ concentrations in soil solution, thereby promoting apatite dissolution (Rajan et al., 1996). High leaching rates on soils with low cation exchange capacity can also increase PR dissolution because the excess water will move $\mathrm{Ca}^{2+}$ and other reaction products away from the vicinity of the dissolving apatite (Rajan et al., 2004). Increasing organic matter content of the soil can also improve the effectiveness of $\mathrm{PR}$ as a $\mathrm{P}$ source because organic matter increases cation exchange capacity, organic acids form complexes with free $\mathrm{Ca}^{2+}$, and organic matter increases titratable acidity (Rajan et al., 2004).

It is difficult to make universally applicable recommendations for PR application because so many factors affect PR dissolution and resultant

\begin{tabular}{|c|c|c|c|c|}
\hline PR source & PR type & Total P & $\frac{\text { Citrate soluble } \mathbf{P}}{\left(\mathrm{g} \cdot \mathrm{kg}^{-1}\right)^{\mathrm{z}}}$ & $\begin{array}{c}\text { Citrate soluble } P \\
(\% \text { total } P)\end{array}$ \\
\hline Algeria ${ }^{y}$ & Sedimentary & 131 & 48 & 37 \\
\hline Gafsa,Tunisia $^{\mathrm{x}}$ & Sedimentary & 127 & 23 & 18 \\
\hline North Carolina ${ }^{\mathrm{x}}$ & Sedimentary & 117 & 20 & 17 \\
\hline Florida ${ }^{y}$ & Sedimentary & 157 & 13 & 8 \\
\hline Tennessee $^{w}$ & Sedimentary & 131 & 11 & 9 \\
\hline Montana $^{y}$ & Igneous & 159 & 8 & 5 \\
\hline Araxa, Brazil ${ }^{w}$ & Igneous & 162 & 6 & 4 \\
\hline
\end{tabular}

Table 3. Total and citrate-soluble phosphorus $(\mathrm{P})$ concentrations in phosphate rock (PR) from various sources. 
efficacy as a $\mathrm{P}$ source for crops. In general, PR use should be limited to soils with $\mathrm{pH}$ less than 5.5 (Bolan and Hedley, 1990; Rajan et al., 2004); however, PR has shown limited success on soils with $\mathrm{pH}$ as high as 8.0 provided there was adequate irrigation and leaching (Singaram et al., 1995). Crop response to PR can be equal to that of commercial phosphate fertilizer on low $\mathrm{pH}$ soils when the PR is from a highly available source and application rates are greater than $65 \mathrm{~kg} \cdot \mathrm{ha}^{-1} \mathrm{P}$ (Adediran et al., 1998; Gatiboni et al., 2003; Zaharah and Bah, 1997). Crop response to $\mathrm{PR}$ at low application rates is often less than that observed with conventional P fertilizers. Dann et al. (1996) found wheat yield increased with single superphosphate applications up to $40 \mathrm{~kg} \cdot \mathrm{ha}^{-1} \mathrm{P}$ but did not find a response to sedimentary $\mathrm{PR}$ applications although $\mathrm{pH}$ was less than 5.5. Other confounding factors could have been low rainfall, PR application method (banded), and low reactivity of PR source. Low annual applications of Gafsa PR (30 $\mathrm{kg} \cdot \mathrm{ha}^{-1}$ per year) resulted in increased forage yields for Scholefield et al. (1999), but crop response was only half that observed from triple superphosphate [TSP; $\mathrm{Ca}\left(\mathrm{H}_{2} \mathrm{PO}_{4}\right)_{2} \cdot \mathrm{H}_{2} \mathrm{O}$ $(0 \mathrm{~N}-20 \mathrm{P}-0 \mathrm{~K})]$ application. Correa et al. (2005) found corn response reached a maximum at their lowest rate of TSP $\left(75 \mathrm{~kg} \cdot \mathrm{ha}^{-1} \mathrm{P}\right)$, but corn yield from Gafsa PR continued to increase until their maximum $\mathrm{P}$ application rate of $225 \mathrm{~kg} \cdot \mathrm{ha}^{-1}$.

Phosphate rock applications to soils with $\mathrm{pH}$ greater than $\mathbf{5 . 5}$ may require higher rates, greater amounts of incorporation, and more time to react before planting (Rajan et al., 2004). Phosphate rock may not reach maximum solubility until 4 to 8 weeks after application (Barnes and Kamprath, 1975). Although lime applications can benefit crop growth by reducing $\mathrm{Al}$ toxicity, increased $\mathrm{pH}$ and $\mathrm{Ca}$ concentrations tend to reduce the efficacy of PR. Gatiboni et al. (2003) found crop response to $\mathrm{PR}$ application was equal to TSP for soils with $\mathrm{pH} 5$, yet combined application of $\mathrm{PR}$ and lime reduced yield, whereas application of TSP with lime doubled yields.

There is some evidence that cultural practices can increase the effectiveness of PR. Zaharah and Bah (1997) found that incorporation of green manures increased the dry matter yield and $\mathrm{P}$ uptake from soils fertilized with either sedimentary or igneous PR. Further research suggests that the decomposition products of the green manures increased the availability of $\mathrm{P}$ or dissolution of $\mathrm{PR}$, thereby increasing $\mathrm{P}$ uptake from between $5 \%$ to $9 \%$ without green manure to between $19 \%$ to $48 \%$ of applied $\mathrm{P}$ with green manure (Bah et al., 2006). Furthermore, Satter et al. (2006) found that arbuscular mycorrhiza also increased $\mathrm{P}$ uptake from Gafsa PR-amended soils, which may have particular applicability in organically managed soils. Although PR has limited solubility and $\mathrm{P}$ availability is highly dependent on soil characteristics, PR may be a preferred $\mathrm{P}$ source in organic production of vegetable crops because, unlike manures and non-National Organic Program-compliant composts, there are not any required waiting periods between application and harvest (U.S. Dept. Agr., 2000).

Manure and compost. In general, manures and composts are good sources of $\mathrm{P}$ with high plant availability. Although manures and composts are organically based nutrient sources, the majority of $\mathrm{P}$ present is inorganic and readily available to plants. Inorganic P accounts for $75 \%$ to $90 \%$ of the total $\mathrm{P}$ present in manure and compost (Eghball et al., 2002). Unlike $\mathrm{N}, \mathrm{P}$ is conserved in the composting process and, depending on the composting process, the watersoluble P of mature compost may not be different from that of the original manure source (Adler and Sikora, 2003). Even compost with very low water extractable $\mathrm{P}$ (less than $0.01 \%$ of total $\mathrm{P}$ ) was found to have high $\mathrm{P}$ availability, in which $\mathrm{P}$ uptake from compost-amended soils did not differ from that receiving equivalent additions of TSP (Sikora and Enkiri, 2005). Other studies have also found that $P$ uptake from manure and compost was equal to or greater than $\mathrm{P}$ uptake from commercial P fertilizers (Eghball and Power, 1999; Leytem and Westermann, 2005).

Although $\mathrm{P}$ availability of manure- or compost-based P may be as great as or greater than that of commercial fertilizers, the soil P reactions are not the same. Increases in soil test $\mathrm{P}$, or measures of plantavailable $\mathrm{P}$, are often less for manure- based $\mathrm{P}$ additions than for equivalent fertilizer P additions (Eghball et al., 2005; Leytem and Westermann, 2005). Griffin et al. (2003) found that that calcium chloride $\left(\mathrm{CaCl}_{2}\right)$ extractable $\mathrm{P}$ increase was greatest with monopotassium phosphate $\left(\mathrm{KH}_{2} \mathrm{PO}_{4}\right)$ addition compared with beef, poultry, swine, and dairy manures. Furthermore, applications of dairy manure up to $800 \mathrm{mg} \cdot \mathrm{kg}^{-1} \mathrm{P}$ soil resulted in decreased $\mathrm{CaCl}_{2}$ extractable P. Research has shown that the increase in soil-test $\mathrm{P}$ after manure additions is inversely related to the C:P ratio of the manure (Leytem et al., 2005). Increases in soil-test $\mathrm{P}$ were also inversely related to microbial biomass $\mathrm{P}$, leading to the hypothesis that increased $\mathrm{C}$ additions stimulated microbial activity and $\mathrm{P}$ immobilization. Because manurebased $\mathrm{P}$ has less of an impact on soil test $\mathrm{P}$ than does commercial fertilizer, it is generally suggested that manure- and compost-based $\mathrm{P}$ should be considered as $70 \%$ available for soils with low soil-test P but 100\% available for soils testing adequate or high for P (Eghball et al., 2002, 2005).

OTHER PHOSPHORUS SOURCES. There are other nutrient sources available for use in organic production that can be good sources of P. Bone meal, prepared by grinding raw animal bones, is one of the earliest $\mathrm{P}$ sources used in agriculture. Although bone meal is often cited as an organically approved $\mathrm{P}$ source, it has a relatively high cost (Parnes, 1986), there are limited supplies (Bekele and Hofner, 1993), and research on its efficacy is limited. The primary calcium $(\mathrm{Ca})$-phosphate mineral in bone material is calcium-deficient hydroxyapatite $\quad\left[\mathrm{Ca}_{10-\mathrm{x}}\left(\mathrm{HPO}_{4}\right)_{\mathrm{x}}\left(\mathrm{PO}_{4}\right)_{6-\mathrm{x}}\right.$ $\left.(\mathrm{OH})_{2-\mathrm{x}}(0<\mathrm{x}<1)\right]$, which is more soluble than PR but much less soluble than conventional $\mathrm{P}$ fertilizers (Dorozhkin, 2007). Calcium-deficient hydroxyapatite present in bone meal would dissolve in soils as follows:

$$
\begin{gathered}
\mathrm{Ca}_{9.5}\left(\mathrm{HPO}_{4}\right)_{0.5}\left(\mathrm{PO}_{4}\right)_{5.5}(\mathrm{OH})_{1.5} \\
+13 \mathrm{H}^{+} \rightleftharpoons 9.5 \mathrm{Ca}^{2+}+6 \mathrm{H}_{2} \mathrm{PO}_{4} \\
+1.5 \mathrm{H}_{2} \mathrm{O} \quad \log \mathrm{K}=47.03 .
\end{gathered}
$$

As can be seen in Eq. 3, increasing $\mathrm{Ca}$ concentrations or increasing $\mathrm{pH}$ would decrease $\mathrm{P}$ release from bone meal. By fixing $\mathrm{Ca}^{2+}$ activity at $10^{-2.5} \mathrm{~mol} \cdot \mathrm{L}^{-1}$, the phosphate 
concentration can be determined as a function of $\mathrm{pH}$ as follows:

$\log \left(\mathrm{H}_{2} \mathrm{PO}_{4}^{-}\right)=11.8-2.17 \mathrm{pH}$

From Eq. 4, one can calculate that bone meal could maintain $\mathrm{P}$ concentration of greater than 1800 $\mathrm{mg} \cdot \mathrm{L}^{-1}$ at $\mathrm{pH} 6$, but could only maintain $\mathrm{P}$ concentration of $0.08 \mathrm{mg} \cdot \mathrm{L}^{-1}$ at $\mathrm{pH} 8$.

Available research has shown that bone meal applications can increase crop growth and crop $\mathrm{P}$ uptake (Meshram et al., 1999; Nimje and Potkile, 1997). Phosphorus availability can be equal to or greater than that of TSP (Bekele and Hofner, 1993 ) and $P$ availability increases with decreasing particle size (Baker et al., 1989). Residual effects of bone meal are equal to or greater than that of TSP (Baker et al., 1989; Bekele and Hofner, 1993). There are not many studies that report soil effects on $\mathrm{P}$ availability from bone meal, but it is generally recommended for use on acid soils (Roy and Holmes, 1984).

Recent concerns with bovine spongiform encephalopathy (BSE) in cattle has raised some concerns about use of bone meal as a fertilizer (B. Baker, personal communication). Although it is conceivable that BSE could be transmitted from raw bone meal containing nerve tissue of infected animals to humans through soil particles on unwashed vegetables, there are no restrictions on the use of bone meal by organic farmers in the National Organic Program rules at this time. Furthermore, based on a review by the European Food Safety Authority (EFSA), there are not any studies defining the fate of BSE prions in soils (EFSA, 2004). In addition, most commercial bone meal products have been heat-treated to the point that any nerve tissue is ashed and the possibility of prion transmission has been eliminated (B. Baker, personal communication).

Guano, more commonly known for its use as an $\mathrm{N}$ fertilizer, can also be used as a P source. Guano is formed from continual deposition of bird or bat droppings beneath roosting sites. As opposed to manure, guano is aged and contains various minerals that concentrate inorganic forms of nutrients. For example, struvite, a magnesium ammonium phosphate mineral, has been identified as a primary component of guano (Cullen, 1988; Grover et al., 1997). Struvite has been used as a slowrelease $\mathrm{N}$ and $\mathrm{P}$ source in the horticultural industry (Bridger et al., 1962; Terman and Taylor, 1965). Struvite can also be precipitated out of swine lagoon liquid (Nelson et al., 2003 ). Although it is only slightly soluble, struvite dissolves in soils as a result of low $\mathrm{NH}_{4}^{+}$concentrations resulting from the nitrification process. As it dissolves, struvite supplies both $\mathrm{N}$ and $\mathrm{P}$ to growing plants. Studies report variable agronomic effectiveness of guano as a $\mathrm{P}$ source, whereas some studies have found guano equal to commercial $\mathrm{P}$ sources (Aliyu and Kuchinda, 2002; Amarante and DeDatta, 1982) and other studies have found the agronomic effectiveness less than readily soluble P sources (Medhi and DeDatta, 1997; Zapata and Arrillaga, 2002).

\section{Environmental issues associated with phosphorus management}

Principles of organic farming systems set forth by the International Federation of Organic Agriculture Movements places environmental protection as a primary objective of organic farming systems (International Federation of Organic Agriculture Movements, 1998; Stockdale et al., 2002). Proper P management is an important part of environmental protection in any agricultural system, especially so in systems that use manures or composts as nutrient sources, because $\mathrm{P}$ inputs to fresh water ecosystems are a primary cause of eutrophication and water quality degradation (Correll, 1998). Algal growth in most freshwater systems is $\mathrm{P}$-limited; therefore, $\mathrm{P}$ inputs increase algal growth. After rapid algal growth, or the algal bloom, algal biomass decomposition reduces dissolved oxygen and can result in fish kills (Sharpley et al., 1994). Phosphorus inputs can also shift the dynamics of the algal community and stimulate growth of toxic blue-green algae (Skulberg et al., 1984). Furthermore, $P$ inputs to salt water have been found to increase the growth of Pfiesteria piscicida, a toxic dinoflagellate linked to fish kills on the eastern coast of the United States (Burkholder and Glasgow, 1997). In general, P-induced algal blooms, low dissolved oxygen, and fish kills result in foul odors, reduced recreational value, reduced biodiversity, and increased treatment costs for fresh water ecosystems and water supplies (Pierzynski et al., 1994). Therefore, organic farming systems should be designed to limit $\mathrm{P}$ losses through proper management of $P$ inputs, cropping systems, and soil resources.

Understanding mechanisms controlling $\mathrm{P}$ loss is essential in determining the appropriate management strategies for reducing $\mathrm{P}$ losses. Phosphorus losses from agricultural systems generally occur through surface runoff and erosion followed by transport to streams and rivers in concentrated flow processes (Sharpley et al., 1994). Phosphorus is transported in both dissolved and particulate forms.

Particulate P losses are highly correlated to erosion rates and soil test $\mathrm{P}$ concentrations, in which increases in either soil test $\mathrm{P}$ or erosion rate will increase P loss (Eghball and Gilley, 2001; Uusitalo et al., 2000). As previously discussed, the use of manures or composts to meet crop $\mathrm{N}$ demands overapplies P. Long-term P applications in excess of crop demand have been found to increase soil test $P$ levels far beyond agronomic requirements, resulting in increased potential for P loss (Chang et al., 2005; Mikkelsen, 2000; Nelson et al., 2005; Whalen and Chang, 2001). Increased soil test $\mathrm{P}$ is also correlated to increased dissolved $\mathrm{P}$ concentrations in runoff (He et al., 2006; Sharpley, 1995). Even on soils with relatively low erosion rates, high soil test $\mathrm{P}$ can result in unacceptable $\mathrm{P}$ losses resulting from high dissolved $\mathrm{P}$ in runoff (Tarkalson and Mikkelsen, 2004a). Soils with high soil test $\mathrm{P}$ represent long-term risks of $\mathrm{P}$ loss because it may take many years before crop removal reduces soil test $\mathrm{P}$ to concentrations below environmental thresholds (Daniel et al., 1994).

Particulate or dissolved $\mathrm{P}$ can also be lost directly from surfaceapplied manures or composts, sometimes referred to as "source P losses" because they are lost directly from the source. Source P losses can sometimes exceed soil $\mathrm{P}$ losses because of the high $\mathrm{P}$ solubility of some sources and reduced interaction and adsorption with soil (Shigaki et al., 2006). 
Excessive source $\mathrm{P}$ losses have also been observed regardless of soil test $P$ levels (Tarkalson and Mikkelsen, 2004b). Therefore, any surface application of manure or compost should be regarded as an increased risk for $\mathrm{P}$ loss.

REDUCING PHOSPHORUS LOSSES. The first step in controlling $\mathrm{P}$ loss from an agricultural system is evaluating the risk of $\mathrm{P}$ loss under current management. Evaluation of $\mathrm{P}$ loss risks will help identify $\mathrm{P}$ sources and $\mathrm{P}$ transport pathways, which may be important targets for best management practices (BMPs) aimed at reducing $\mathrm{P}$ loss. Phosphorus loss indices, conceptualized by Lemunyon and Gilbert (1993), have been developed and used in 47 states in the United States as well as a few European Union countries (Andersen and Kronvang, 2006; Bechmann et al., 2005; Sharpley et al., 2003). Phosphorus loss indices the rate the relative risk of $\mathrm{P}$ loss by evaluating field-specific $\mathrm{P}$ sources and transport factors and assigning each a $\mathrm{P}$ risk rating. Most state-specific $\mathrm{P}$ indices are designed such that in the process of evaluating $P$ loss risk, the user also identifies the major contributing factors to $P$ losses. Once these factors have been identified, BMPs can be selected to address the specific risks.

There are a variety of best management practices that can be used to reduce $\mathrm{P}$ loss from agricultural systems. Because P is strongly adsorbed to soil particles, erosion control is one of the primary ways to reduce P losses. A few of the more common erosion control BMPs are contour farming, terracing, reduced tillage, grassed waterways, and cover crops, each of which will also reduce the risk of $\mathrm{P}$ loss (Hartz, 2006; Sharpley et al., 2004). Although BMPs that stop erosion before it begins are preferred, BMPs designed to trap eroded sediments as they leave the field such as grassed buffer strips are also effective at reducing particulate $\mathrm{P}$ losses (Heathwaite et al., 1998). Because organic farming systems do not use herbicides, continuous no tilling may not be a feasible BMP; however, short-term no tilling, rotation with cover crops, grassed waterways, and field buffers may be particularly well suited to organic farming.

Although erosion control methods may reduce the majority of $\mathrm{P}$ losses, they may not reduce and may even increase dissolved $\mathrm{P}$ losses (Parsons et al., 1994; Uusi-Kamppa et al., 2000; Zeimen et al., 2006). Dissolved $\mathrm{P}$ losses can be reduced by increasing infiltration rates, thereby reducing runoff volume (Andraski et al., 2003; Franklin et al., 2007). Infiltration can be increased through proper residue management and maintaining good soil structure (Grande et al., 2005). Increasing soil organic matter, one objective of organic production, has been found to increase infiltration rates (Lado et al., 2004).

Maintaining moderate soil test $\mathrm{P}$ concentrations or reducing high soil test $\mathrm{P}$ concentrations can reduce $\mathrm{P}$ lost from both erosion and dissolved $\mathrm{P}$ in runoff. Balancing $\mathrm{P}$ inputs with crop removal is an essential part of a long-term sustainable solution to controlling $\mathrm{P}$ losses. This may require producers who currently use animal manure or compost as the primary $\mathrm{N}$ source to switch to alternate $\mathrm{N}$ sources such as use of legumes as a green manure. Continual crop removal of $P$ in absence of $\mathrm{P}$ inputs will reduce soil test $\mathrm{P}$; however, reduction of soil test $\mathrm{P}$ through crop uptake may require many years (Pierzynski and Logan, 1993 ).

Phosphorus application BMPs would be an important part of environmentally sound $\mathrm{P}$ management in organic agriculture because of the frequency of manure or compost additions. One of the most effective methods of reducing source $\mathrm{P}$ losses is to incorporate the $\mathrm{P}$ source into the soil through tillage immediately after application (Tarkalson and Mikkelsen, 2004b). Incorporation reduces the $\mathrm{P}$ source interaction with runoff water and increases $P$ source interaction with soil, both of which tend to reduce P losses (Daverede et al., 2004). Phosphorus application timing can also have a strong impact on source P losses. Phosphorus applications immediately followed by rainfall tend to result in greater $\mathrm{P}$ losses than when several days or weeks separate the application from precipitation events (Sharpley, 1997). Application timing BMPs are specific to climatic regimes, but in general, manure and compost applications should be made during periods with low risk of runoff being generated from either rainfall or snow melt (Gilley et al., 2002).

\section{Conclusions}

Organic production systems seek to improve soil organic matter and biological diversity, which may impact $\mathrm{P}$ cycling and $\mathrm{P}$ uptake by crops. Increases in organic matter will be accompanied by increases in organic P. Management of cover crops and potentially enhanced AMF colonization can increase the availability of soil $P$ pool (both organic and inorganic) by stimulating microbial activity and release of root exudates. This can help compensate for low soil $\mathrm{P}$, but will not supersede the need to replace $P$ removed by the harvested crop.

Phosphorus fertilization in organic production systems entails balancing the $\mathrm{P}$ inputs with crop removal through selection and management of both $\mathrm{N}$ and $\mathrm{P}$ inputs. Organic production systems that do not rely on manure or composts for meeting crop $\mathrm{N}$ demand may have a $\mathrm{P}$ deficit. In such situations, maintenance $\mathrm{P}$ applications equal to crop removal should be made based on soil test recommendations. Primary organically approved P sources are PR, manure, and compost. Phosphate rock is most effective at supplying $\mathrm{P}$ in soils with low $\mathrm{pH}$ (less than 5.5) and low calcium concentrations. Phosphate rock applications made to soils with $\mathrm{pH}$ greater than $\mathbf{5 . 5}$ may not be effective because of reduced PR solubility. Manure- and compostbased $\mathrm{P}$ has high plant availability, ranging from $70 \%$ to $100 \%$ available. Use of manures and composts require extra considerations to reduce the risk of source P loss to surface waters. Best management practices for reducing source P losses are incorporation and proper application timing.

Organic production systems that use manures and composts as their primary $\mathrm{N}$ source are likely to have excess $\mathrm{P}$ accumulation in the soil, and $\mathrm{P}$ management should focus on reducing the risks of $P$ loss to surface waters. Evaluation of P loss risk with a $\mathrm{P}$ index will assist in identification of soil and management factors likely to contribute to high $\mathrm{P}$ loss as well as BMPs that can decrease P loss risks. Best management practices should focus on controlling both particulate and dissolved P losses. Economic considerations, local availability, as well as amount of $\mathrm{P}$ required to meet crop needs will also play a role in a 
producer's final decision on which source, or combination of sources, to use in an organic production system.

\section{Literature cited}

Adediran, J.A., F.I. Oguntoyinbo, R. Omonode, and R.A. Sobul. 1998. Evaluation of phosphorus availability from three phosphorus sources in Nigerian soils. Comm. Soil Sci. Plant Analysis 29:2659-2673.

Adler, P.R. and L.J. Sikora. 2003. Changes in soil phosphorus availability with poultry compost age. Comm. Soil Sci. Plant Analysis 34:81-95.

Aliyu, L. and N.C. Kuchinda. 2002. Analysis of the chemical composition of some organic manures and their effect on the yield and composition of pepper. Crop Res. Hisar 23:362-368.

Amarante, S.T. and S.K. DeDatta. 1982. Residual effects of phosphorus fertilizers in lowland rice in the Philippines. Philippines J. Crop Sci. 7:117-122.

Andersen, H.E. and B. Kronvang. 2006. Modifying and evaluating a P index for Denmark. Water Air Soil Pollut. 174: 341-353.

Andraski, T.W., L.G. Bundy, and K.C. Kilian. 2003. Manure history and longterm tillage effects on soil properties and phosphorus losses in runoff. J. Environ. Qual. 35:1782-1789.

Bah, A.R., A.R. Zaharah, and A. Hussin. 2006. Phosphorus uptake from green manures and phosphate fertilizers in an acid tropical soil. Comm. Soil Sci. Plant Analysis 37:2077-2093.

Baker, A.M., J.R. Trimm, and F.J. Sikora. 1989. Availability of phosphorus in bone meal. J. Assn. Offic. Anal. Chem. 72:867869.

Barnes, J.S. and E.J. Kamprath. 1975. Availability of North Carolina rock phosphate applied to soils. North Carolina Agr. Expt. Sta. Tech. Bul. 229.

Bechmann, M., T. Krogstad, and A. Sharpley. 2005. A phosphorus index for Norway. Acta Agr. Scan. Sect. B-Soil Plant Sci. 55:205-213.

Bekele, T. and W. Hofner. 1993. Effects of different phosphate fertilizers on yield of barley and rape seed on reddish brown soils of the Ethiopian highlands. Fert. Res. 34:243-250.

Berry, P.M., E.A. Stockdale, R. SylvesterBradley, L. Philipps, K.A. Smith, E.I. Lord, C.A. Watson, and S. Fortune. 2003. N, P and K budgets for crop rotations on nine organic farms in the UK. Soil Use Mgt. 19:112-118.
Bolan, N.S. and M.J. Hedley. 1990. Dissolution of phosphate rocks in soils. 2. Effect of $\mathrm{pH}$ on the dissolution and plant availability of phosphate rock in soil with pH dependent charge. Fert. Res. 24:125134.

Bridger, G.L., M.L. Salutsky, and R.W. Starostka. 1962. Metal ammonium phosphates as fertilizers. J. Agr. Food Chem. 10:181-188.

Burkholder, J.M. and H.B. Glasgow. 1997. Pfiesteria piscicida and other Pfiesteria-like dinoflagellates: Behavior, impacts, and environmental controls. Limnol. Oceanogr. 42:1052-1075.

Cavigelli, M.A. and S.J. Thien. 2003. Phosphorus bioavailability following incorporation of green manure crops. Soil Sci. Soc. Am. J. 67:1186-1194.

Centre for Industrial Development. 1967. Fertilizer manual. United Nations, New York.

Chang, C., J.K. Whalen, and X.Y. Hao. 2005. Increase in phosphorus concentration of a clay loam surface soil receiving repeated annual feedlot cattle manure applications in southern Alberta. Can. J. Soil Sci. 85:589-597.

Clark, M.S., H. Ferris, K. Klonsky, W.T. Lanini, A.H.C. vanBruggen, and F.G. Zalom. 1998. Agronomic, economic, and environmental comparison of pest management in conventional and alternative tomato and corn systems in northern California. Agr. Ecosystems Environ. 68:51-71.

Correa, R.M., C.W.A. do Nascimento, S.K. De Sa Souza, F.J. Freire, and G.B. da Silva. 2005. Gafsa rock phosphate and triple super phosphate for dry matter production and $\mathrm{P}$ uptake by corn. Sci. Agr. 62:159-164.

Correll, D.L. 1998. The role of phosphorus in the eutrophication of receiving waters: A review. J. Environ. Qual. 27:261-266.

Cullen, D.J. 1988. Mineralogy of nitrogenous guano on the bounty islands SW Pacific ocean. Sedimentology 35:421428.

Daniel, T.C., A.N. Sharpley, D.R. Edwards, R. Wedepohl, and J.L. Lemunyon. 1994. Minimizing surface water eutrophication from agricultural by phosphorus management. J. Soil Water Conservation 49:30-38.

Dann, P.R., J.W. Derrick, D.C. Dumaresq, and M.H. Ryan. 1996. The response of organic and conventionally grown wheat to superphosphate and reactive phosphate rock. Austral. J. Expt. Agr. 36:71-78.
Daverede, I.C., A.N. Kravchenko, R.G. Hoeft, E.D. Nafzinger, D.G. Bullock, J.J. Warren, and L.C. Gonzini. 2004. Phosphorus runoff from incorporated and surface-applied liquid swine manure and phosphorus fertilizer. J. Environ. Qual. 33:1535-1544.

DeLaune, P.B., P.A. Moore, Jr., and J.L. Lemunyon. 2006. Effect of chemical and microbial amendment on phosphorus runoff from composted poultry litter. J. Environ. Qual. 35:1291-1296.

Dodd, J.R. and A.P. Mallarino. 2005. Soil-test phosphorus and crop grain yield responses to long-term phosphorus fertilization for corn-soybean rotations. Soil Sci. Soc. Amer. J. 69:1118-1128.

Dorozhkin, S.V. 2007. Calcium orthophosphates. J. Mater. Sci. 42:1061-1095.

Douds D.D., Jr., R.R. Janke, and S.E. Peters. 1993. VAM fungus spore populations and colonization of roots of maize and soybean under conventional and lowinput sustainable agriculture. Agr. Ecosystems Environ. 43:325-335.

Drinkwater, L.E., P. Wagoner, and M. Sarrantonio. 1998. Legume-based cropping systems have reduced carbon and nitrogen losses. Nature 396:262-265.

Eakin, J.H. 1976. Food and fertilizers, p. 1-21. In: W.C. White and D.N. Collins (eds.). The fertilizer handbook. Fertilizer Institute, Washington, DC.

Eghball, B. and J.E. Gilley. 2001. Phosphorus risk assessment index evaluation using runoff measurements. J. Soil Water Conservation 56:202-206.

Eghball, B. and J.F. Power. 1999. Phosphorus and nitrogen-based manure and compost applications:.Corn production and soil phosphorus. Soil Sci. Soc. Amer. J. 63:895-901.

Eghball, B., B.J. Wienhold, J.E. Gilley, and R.A. Eigenberg. 2002. Mineralization of manure nutrients. J. Soil Water Conservation 57:470-473.

Eghball, B., B.J. Wienhold, B.L. Woodbury, and R.A. Eigenberg. 2005. Plant availability of phosphorus in swine slurry and cattle feedlot manure. Agron. J. 97: 542-548.

Elmaz, O., H. Cerit, M. Ozcelik, and S. Ulas. 2004. Impact of organic agriculture on the environment. Fresenius Environ. Bul. 13:1072-1078.

European Food Safety Authority. 2004. Safety vis-à-vis biological risk including TSEs of the application on pastureland of organic fertilisers and soil improvers. EFSA J. 40:1-10. 
Faucette, L.B., L.M. Risse, M.A. Nearing, J.W. Gaskin, and L.T. West. 2004. Runoff, erosion, and nutrient losses from compost and mulch blankets under simulated rainfall. J. Soil Water Conservation 59:154-160.

Felton, G.K., L.E. Carr, C.E. Prigge, and J.C. Bouwkamp. 2004. Nitrogen and phosphorous dynamics in cocomposted yard trimmings and broiler litter. Compost Sci. Util. 12:349-355.

Franklin, D.H., M.L. Cabrera, L.T. West, V.H. Calvert, and J.A. Rema. 2007. Aerating grasslands: Effects on runoff and phosphorus losses from applied broiler litter. J. Environ. Qual. 36:208-215.

Gagnon, B. 2004. Contribution of onfarm and industrial composts to soil $\mathrm{pH}$ and enrichment in available nutrients and metals. Can. J. Soil Sci. 84:439445 .

Galvez, L., D.D. Douds, Jr., P. Wagoner, L.R. Longnecker, L.E. Drinkwater, and R.R. Janke. 1995. An overwintering cover crop increases inoculum of VAM fungi in agricultural soil. Amer. J. Alternative Agr. 10:152-156.

Gaskell, M. and R. Smith. 2007. Organic nitrogen sources for vegetable crops. HortTechnology 17:431-441.

Gatiboni, L.C., J. Kaminski, D.S. Rheinheimer, and G. Brunetto. 2003. Superphosphate and rock phosphates as phosphorus sources for grass-clover pasture on a limed acid soil in southern Brazil. Comm. Soil Sci. Plant Analysis 34:2503-2514.

Gilley, J.E., L.M. Risse, and B. Eghball. 2002. Managing runoff following manure application. J. Soil Water Conservation 57:530-533.

Gosling, P., A. Hodge, G. Goodlass, and G.D. Bending. 2006. Arbuscular mycorrhizal fungi and organic farming. Agr. Ecosystems Environ. 113:17-35.

Gosling, P. and M. Shepherd. 2005. Long-term changes in soil fertility in organic arable farming systems in England, with particular reference to phosphorus and potassium. Agr. Ecosystems Environ. 105:425-432.

Grande, J.D., K.G. Karthikeyan, P.S. Miller, and J.M. Powell. 2005. Corn residue level and manure application timing effects on phosphorus losses in runoff. J. Environ. Qual. 34:1620-1631.

Griffin, T.S., C.W. Honeycutt, and Z. He. 2003. Changes in soil phosphorus from manure application. Soil Sci. Soc. Amer. J. 67:645-653.

Grover, J.E., A.F. Rope, and E.S. Kaneshiro. 1997. The occurrence of biogenic calcian struvite, $(\mathrm{Mg}, \mathrm{Ca}) \mathrm{NH}_{4} \mathrm{PO}_{4} \cdot 6 \mathrm{H}_{2} \mathrm{O}$, as intracellular crystals in Paramecium. J. Eukaryot. Microbiol. 44:366-373.

Haas, G., B. Caspari, and U. Kopke. 2002. Nutrient cycling in organic farms: Stall balance of a suckler cow herd and beef bulls. Nutrient Cycling Agroecosystems 64:225-230.

Hadas, A., L. Kautsky, and R. Portnoy. 1996. Mineralization of composted manure and microbial dynamics in soil as affected by long-term nitrogen management. Soil Biol. Biochem. 28:733-738.

Hartz, T.K. 2006. Vegetable production best management practices to minimize nutrient loss. HortTechnology 16:398403.

Havlin, J.L., J.D. Beaton, S.L. Tisdale, and W.L. Nelson. 2004. Soil fertility and fertilizers: An introduction to nutrient management, 7 th ed. Prentice-Hall, Upper Saddle River, NJ.

He, Z., T.S. Griffin, and C.W. Honeycutt. 2004. Phosphorus distribution in dairy manures. J. Environ. Qual. 33:15281534 .

He, Z.L., M.K. Zhang, P.J. Stoffella, X.E. Yang, and J.J. Banks. 2006. Phosphorus concentrations and loads in runoff water under crop production. Soil Sci. Soc. Amer. J. 70:1807-1816.

Heathwaite, A.L., P. Griffiths, and R.J. Parkinson. 1998. Nitrogen and phosphorus in runoff from grassland with buffer strips following application of fertilizers. Soil Use Mgt. 14:142-148.

Horst, W.J., M. Kamh, J.M. Jibrin, and V.O. Chude. 2001. Agronomic measures for increasing $\mathrm{P}$ availability to crops. Plant Soil 237:211-223.

International Federation of Organic Agriculture Movements. 1998. IFOAM basic standards for organic production and processing. IFOAM Publications, TholeyTheley, Germany.

Jaber, F.H., S. Shukla, E.A. Hanlon, P.J. Stoffella, T.A. Obreza, and H.H. Bryan. 2006. Groundwater phosphorus and trace element concentrations from organically amended sandy and calcareous soils of Florida. Compost Sci. Util. 14:6-15.

Jeffries, P., S. Gianninazzi, S. Perotto, K. Turnau, and J.-M. Barea. 2003. The contribution of arbuscular mycorrhizal fungi in sustainable maintenance of plant health and soil fertility. Biol. Fertil. Soils 37:1-16

Kahiluoto, H. and M. Vestberg. 1998. The effect of arbuscular mycorrhiza on biomass production and phosphorus uptake from sparingly soluble sources by leek (Allium porrum L.) in Finnish field soils. Biol. Agr. Hort. 16:65-85.

Kasawneh, F.E. and E.C. Doll. 1978. The use of phosphate rock for direct application to soils. Adv. Agron. 30: 159-206.

Kleinman, P.J.A., A.N. Sharpley, B.G. Moyer, and G.F. Elwinger. 2002. Effect of mineral and manure phosphorus sources on runoff phosphorus. J. Environ. Qual. 31:2026-2033.

Klock-Moore, K.A. 2000. Comparison of slavia growth in seaweed compost and biosolids compost. Compost Sci. Util. 8:24-28.

Lado, M., A. Paz, and M. Ben-Hur. 2004. Organic matter and aggregate size interactions in infiltration, seal formation, and soil loss. Soil Sci. Soc. Amer. J. 68:935942.

Larney, F.J., K.E. Buckley, X. Hao, and W.P. McCaughey. 2006. Fresh, stockpiled, and composted beef cattle feedlot manure: Nutrient levels and mass balance estimates in Alberta and Manitoba. J. Environ. Qual. 35:1844-1854.

Lemunyon, J.L. and R.G. Gilbert. 1993. The concept and need for a phosphorus assessment tool. J. Production Agr. 6:483-486.

Leytem, A.B., B.L. Turner, V. Raboy, and K.L. Peterson. 2005. Linking manure properties to phosphorus solubility in calcareous soils: Importance of the manure carbon to phosphorus ratio. Soil Sci. Soc. Amer. J. 69:1516-1524.

Leytem, A.B. and D.T. Westermann. 2005. Phosphorus availability to barley from manures and fertilizers on a calcareous soil. Soil Sci. 170:401-412.

Liebig, M.A. and J.W. Doran. 1999. Impact of organic production practices on soil quality indicators. J. Environ. Qual. 28:1601-1609.

Lindsay, W.L. 1979. Chemical equilibria in soils. Wiley, New York.

Lisk, D.J., W.H. Guenmann, M. Rutzke, H.T. Kuntz, and G. Chu. 1992a. Survey of toxicants and nutrients in composted waste materials. Arch. Environ. Contam. Toxicol. 22:190-194.

Lisk, D.J., W.H. Guenmann, M. Rutzke, H.T. Kuntz, and G.J. Doss. 1992b. Composition of toxicants and other constituents in yard or sludge composts from the same community as a function of time-ofwaste-collection. Arch. Environ. Contam. Toxicol. 22:380-383.

Lotter, D.W. 2003. Organic agriculture. J. Sustainable Agr. 21:59-128. 
Mader, P., A. Fliebback, D. Duibois, L. Gunst, P. Fried, and U. Niggli. 2002. Soil fertility and biodiversity in organic farming. Science 296:1694-1697.

McAndrews, G.M., M. Liebman, C.A. Cambardella, and T.L. Richard. 2006. Residual effects of composted and fresh solid swine (Sus scrofa L.) manure on soybean [Glycine max (L.) Merr.] growth and yield. Agron. J. 98:873-882.

Medhi, D.N. and S.K. DeDatta. 1997. Phosphorus availability to irrigated lowland rice as affected by sources, application level and green manure. Nutrient Cycling Agroecosystems 46:195-203.

Meshram, T.T., A.C. Jadhav, B.K. Konde, and P.V. Wani. 1999. Effect of VAM fungi and P-sources on nutrient uptake and yield of chickpea. J. Maharashtra Agr. Univ. 24:340-341.

Michel F.C., Jr. and C.A. Reddy. 1998. Effect of oxygenation level on yard trimmings composting rate, odor production, and compost quality in bench-scale reactors. Compost Sci. Util. 6:6-14.

Mikkelsen, R.L. 2000. Nutrient management for organic farming: A case study. J. Natural Resource Life Sci. Educ. 29: 88-92.

Montgomery, M.B., T. Ohno, T.S. Griffin, C.W. Honeycutt, and I.J. Fernanadez. 2005. Phosphorus mineralization and availability in soil amended with biosolids and animal manures. Biol. Agr. Hort. 22:321-334

Muleba, N. 1999. Effects of cowpea, crotalaria and sorghum crops and phosphorus fertilizers on maize productivity in semi-arid West Africa. J. Agr. Sci. 132: 61-70.

Nelson, N.O., R.L. Mikkelsen, and D.L. Hesterberg. 2003. Struvite precipitation in anaerobic swine lagoon liquid: Effect of $\mathrm{pH}, \mathrm{Mg}: \mathrm{P}$ ratio, and determination of rate constant. Bioresour. Technol. 89: 229-236.

Nelson, N.O., J.E. Parsons, and R.L. Mikkelsen. 2005. Field-scale evaluation of phosphorus leaching in acid sandy soils receiving long-term swine waste applications. J. Environ. Qual. 34:2024-2035.

Newman, E.I. 1997. Phosphorus balance of contrasting farming systems, past and present. Can food production be sustainable? J. Appl. Ecol. 34:1334-1347.

Nimje, B.H. and S.N. Potkile. 1997. Biochemical studies in soybean as influenced by different sources and levels of phosphorus. J. Phytol. Res. 10:103-105.

Nuruzzaman, M., H. Lambers, M.D.A. Bolland, and E.J. Veneklaas. 2005. Phosphorus benefits of different legume crops to subsequent wheat grown in different soils of western Australia. Plant Soil 271:175-187.

Parnes, R. 1986. Organic and inorganic fertilizers. Woods End Agricultural Institute, Mt. Vernon, ME.

Parsons, J.E., J.W. Gilliam, R. MunozCarpena, R.B. Daniels, and T.A. Dillaha 1994. Nutrient and sediment removal by grass and riparian buffers, p. 147-154. In: K.L. Campbell, W.D. Graham, and A.B Bottcher (eds.). Environmentally sound agriculture. Proc. 2nd Conference. Amer. Soc. Agr. Eng., St. Joseph, MI.

Pierzynski, G.M. and T.J. Logan. 1993. Crop, soil, and management effects on phosphorus soil test levels: A review. J. Production Agr. 6:513-520.

Pierzynski, G.M., J.T. Sims, and G.F. Vance. 1994. Soils and environmental quality. CRC Press, Boca Raton, FL.

Rajan, S.S.S., E. Casanova, and B. Truong. 2004. Factors affecting the agronomic effectiveness of phosphate rocks, with a case-study analysis, p. 41-57. In: F. Zapata and R.N. Roy (eds.). Use of phosphate rocks for sustainable agriculture. FAO Fert. Plant Nutr. Bul. 13. Food and Agr. Organization of the United Nations, Rome.

Rajan, S.S.S., J.H. Watkinson, and A.G. Sinclair. 1996. Phosphate rocks for direct application to soils. Adv. Agron. 57:78160.

Randhawa, P.S., L.M. Condron, H.J. Di, S. Sinaj, and R.D. McLenaghen. 2005. Effect of green manure addition on soil organic phosphorus mineralization. Nutrient Cycling Agroecosystems 73: 181-189.

Read, J.J., G.E. Brink, J.L. Oldham, W.L. Kingery, and K.R. Sistani. 2006. Effects of broiler litter and nitrogen fertilization on uptake of major nutrients by coastal bermudagrass. Agron. J. 98:1065-1072.

Reganold, J.P., A.S. Palmer, J.C. Lockhart, and A.N. Macgregor. 1993. Soil quality and financial performance of biodynamic and conventional farms in New Zealand. Science 260:344-349.

Roy, R.N. and M. Holmes. 1984. Fertilizer and plant nutrient guide. FAO Fert Plant Nutr. Bul. 9. Food and Agriculture Organization of the United Nations, Rome.

Satter, M.A., M.M. Hanafi, T.M.M. Mahmud, and H. Azizah. 2006. Role of arbuscular mycorrhiza and phosphorus in Acacia mangium-peanut agro forestry system for rejuvenation of tin tailings. J. Sustainable Agr 28:55-68.
Scholefield, D., R.D. Sheldrick, T.M. Martyn, and R.H. Lavender. 1999. A comparison of triple superphosphate and Gafsa ground rock phosphate fertilizers as P-sources for grass-clover swards on a poorly-drained acid clay soil. Nutrient Cycling Agroecosystems 53:147-155.

Seiter, S. and W.R. Horwath. 2004. Strategies for managing soil organic matter to supply plant nutrients, p. 269-293. In: F. Magdoff and R. Weil (eds.). Soil organic matter in sustainable agriculture. CRC Press, Boca Raton, FL.

Sharpley, A.N. 1997. Rainfall frequency and nitrogen and phosphorus runoff from soil amended with poultry litter. J. Environ. Qual. 26:1127-1132.

Sharpley, A., P. Kleinman, and J. Weld. 2004. Assessment of best management practices to minimize the runoff of manure-born phosphorus in the United States. N.Z. J. Agr. Res. 47:461-477.

Sharpley, A.N. 1995. Dependence of runoff phosphorus on extractable soil phosphorus. J. Environ. Qual. 24:920-926.

Sharpley, A.N., S.C. Chapra, R. Wedepohl, J.T. Sims, T.C. Daniel, and K.R. Reddy. 1994. Managing agricultural phosphorus for protection of surface waters: Issues and options. J. Environ. Qual. 23:437-451.

Sharpley, A.N., J.L. Weld, D.B. Beegle, P.J.A. Kleinman, W.J. Gburek, P.A. Moore, and G. Mullins. 2003. Development of phosphorus indices for nutrient management planning strategies in the United States. J. Soil Water Conservation 58:137-152

Shigaki, F., A. Sharpley, and L.I. Prochnow. 2006. Source-related transport of phosphorus in surface runoff. J. Environ. Qual. 35:2229-2235.

Sikora, L.J. and N.K. Enkiri. 2005. Comparison of phosphorous uptake from poultry litter compost with triple super phosphate in codorous soil. Agron. J. 97:668-673.

Singaram, P., S.S.S. Rajan, and G.V. Kothandaraman. 1995. Phosphate rock and a phosphate rock/superphosphate mixture as fertilizers for crops grown on a calcareous soil. Comm. Soil Sci. Plant Analysis 26:1571-1583.

Singer, J.W., K.A. Kohler, M. Liebman, T.L. Richard, C.A. Cambardella, and D.D. Buhler. 2004. Tillage and compost affect yield of corn, soybean, and wheat and soil fertility. Agron. J. 96:531-537.

Skulberg, O.M., G.A. Codd, and W.W. Carmichael. 1984. Blue-green algal blooms in Europe: A growing problem. Ambio 13:244-247. 
Sleugh, B.B., R.A. Gilfillen, W.T. Willian, and H.D. Henderson. 2006. Nutritive value and nutrient uptake of sorghumsudangrass under different broiler litter fertility programs. Agron. J. 98:15941599.

Stockdale, E.A., N.H. Lampkin, M. Hovi, R. Keatinge, E.K.M. Lennartsson, D.W. Macdonald, S. Padel, F.H. Tattersall, M.S. Wolfe, and C.A. Watson. 2001. Agronomic and environmental implications of organic farming systems. Adv. Agron. 70:261-327.

Stockdale, E.A., M.A. Shepherd, S. Fortune, and S.P. Cuttle. 2002. Soil fertility in organic farming systems-Fundamentally different? Soil Use Mgt. 18:301308 .

Tarkalson, D.D. and R.L. Mikkelsen. 2004a. Runoff phosphorus losses as related to soil test phosphorus and degree of phosphorus saturation on piedmont soils under conventional and no-tillage. Comm. Soil Sci. Plant Analysis 35:29873007.

Tarkalson, D.D. and R.L. Mikkelsen. 2004b. Runoff phosphorus losses as related to phosphorus source, application method, and application rate on a piedmont. J. Environ. Qual. 33:1424-1430.

Terman, G.L. and A.W. Taylor. 1965. Crop response to nitrogen and phosphorus in metal ammonium phosphates. J. Agr. Food Chem. 13:497-500.

Toth, J.D., Z. Dou, J.D. Ferguson, D.T. Galligan, and C.F. Ramberg, Jr. 2006. Nitrogen- vs. phosphorus-based dairy manure applications to field crops: Nitrate and phosphorus leaching and soil phos- phorus accumulation. J. Environ. Qual. 35:2302-2312.

U.S. Dept. Agr. 2000. National Organic Program regulatory text, Section $\$$ 205.203c Soil fertility and crop nutrient management practice standard. 27 Apr. 2007. <http://www.ams.usda. gov/NOP/NOP/standards/Full Text.pdf>.

Uusi-Kamppa, J., B. Braskerud, H. Jansson, N. Syversen, and R. Uusitalo. 2000. Buffer zones and constructed wetlands as filters for agricultural phosphorus. J. Environ. Qual. 29:151-158.

Uusitalo, R., M. Yli-Halla, and E. Turtola. 2000. Suspended soil as a source of potentially bioavailable phosphorus in surface runoff waters from clay soils. Water Res. 34:2477-2482.

Van Kauwenbergh, S.J. and G.H. McClellan. 2004. Characterization of phosphate rocks, p. 17-26. In: F. Zapata and R.N. Roy (eds.). Use of phosphate rocks for sustainable agriculture. FAO Fert. Plant Nutr. Bul. 13. Food and Agriculture Organization of the United Nations, Rome.

Walz, E. 1999. Final results of the third biannual national organic farmers' survey. Organic Farming Res. Foundation, Santa Cruz, CA.

Watson, C.A., D. Atkinson, P. Gosling, L.R. Jackson, and F.W. Rayns. 2002a. Managing soil fertility in organic farming systems. Soil Use Mgt. 18:239-247.

Watson, C.A., H. Bengtsson, M. Ebbesvik, A.-K. Loes, A. Myrbeck, E. Salomon, J. Schroder, and E.A. Stockdale. 2002b. A review of farm-scale nutrient budgets for organic farms as a tool for management of soil fertility. Soil Use Mgt. 18:264-273.

Whalen, J.K. and C. Chang. 2001. Phosphorus accumulation in cultivates oils from long-term annual applications of cattle feedlot manure. J. Environ. Qual. 30:229-237.

Zaharah, A.R. and A.R. Bah. 1997. Effect of green manures on $\mathrm{P}$ solubilization and uptake from phosphate rocks. Nutrient Cycling Agroecosystems 48:247-255.

Zapata, F. and J.L. Arrillaga. 2002. Agronomic evaluation of guano sources by means of isotope techniques, p. 83-89. In: Assessment of soil phosphorus status and management of phosphatic fertilisers to optimise crop production. IAEATECDOC 1272. International Atomic Energy Agency, Vienna, Austria.

Zapata, F. and R.N. Roy. 2004. Use of phosphate rocks for sustainable agriculture. FAO Fert. Plant Nutr. Bul. 13. Food and Agriculture Organization of the United Nations, Rome.

Zeimen, M.B., K.A. Janssen, D.W. Sweeney, G.M. Pierzynski, K.G. Mankin, D.L. Devlin, D.L. Regehr, M.R. Langemeier, and K.A. McVay. 2006. Combining management practices to reduce sediment, nutrients, and herbicides in runoff. J. Soil Water Conservation 61:258-267.

Zvomuya, F., B.L. Helgason, F.J. Larney, H.H. Janzen, O.O. Akinremi, and B.M. Olson. 2006. Predicting phosphorus availability from soil-applied composted and non-composted cattle feedlot manure. J. Environ. Qual. 35:928-937. 